\title{
La problématique du gouvernement responsable des marchands ruraux dans six paroisses de la plaine de Montréal, 1831 à 1861
}

\author{
BUCKNER, Phillip A., The Transition to Responsible
}

Government: British Policy in British North America, 1815-1850. Westport, Conn., Greenwood Press, 1985. viii-358 p. $35,00 \$$

\section{Pierre Tousignant}

Volume 42, numéro 2, automne 1988

URI : https://id.erudit.org/iderudit/304680ar

DOI : https://doi.org/10.7202/304680ar

Aller au sommaire du numéro

Éditeur(s)

Institut d'histoire de l'Amérique française

ISSN

0035-2357 (imprimé)

1492-1383 (numérique)

Découvrir la revue

Citer cette note

Tousignant, P. (1988). La problématique du gouvernement responsable des marchands ruraux dans six paroisses de la plaine de Montréal, 1831 à 1861 / BUCKNER, Phillip A., The Transition to Responsible Government: British Policy in British North America, 1815-1850. Westport, Conn., Greenwood Press, 1985. viii-358 p. 35,00 \$. Revue d'histoire de l'Amérique française, 42(2), 253-261. https://doi.org/10.7202/304680ar d'utilisation que vous pouvez consulter en ligne. 


\section{NOTE CRITIQUE}

\section{LA PROBLÉMATIQUE DU GOUVERNEMENT RESPONSABLE VUE DANS UNE NOUVELLE PERSPECTIVE HISTORIQUE}

BUCKNER, Phillip A., The Transition to Responsible Government: British Policy in British North America, 1815-1850. Westport, Conn., Greenwood Press, 1985. viii-358 p. 35,00\$

En conclusion de son compte rendu critique paru dans la Canadian Historical Review (68,1 (mars 1987): 131-133), Ged Martin faisait ainsi l'éloge de cet important ouvrage: «This is, in every sense, a giant of a book. Inevitably, it will take time for the full import and impact of Buckner's arguments to be digested by historians.» Voilà un jugement susceptible de rendre plus acceptable la parution tardive de la présente recension.

Reconnaissons-le de prime abord, nous sommes en présence d'un ouvrage conçu pour des lecteurs familiers avec l'historiographie du sujet traité. Dès l'introduction, l'auteur prend pour acquis qu'il s'adresse à des initiés qui sauront dépister dans le développement de son exposé ses positions «anti-révisionnistes, aussi bien que révisionnistes». Et de fait, les initiés eux-mêmes, en s'adonnant à ce travail de dépistage, trouveront ample matière à mesurer l'état de leurs connaissances historiographiques.

Le titre de l'ouvrage en définit bien l'objet: démontrer comment s'est opérée et effectuée «la transition au gouvernement responsable». Mais dès l'introduction, l'auteur nous laisse entrevoir le long et laborieux cheminement de sa démonstration afin de faire valoir ses positions «anti-révisionnistes, aussi bien que révisionnistes». «The major weakness in virtually everything written about the transition to responsible government in British North America is the teleological frame of reference in which the discussion has been cast.» (p.6) Et à l'encontre d'une historiographie qui, dans ce «cadre de référence téléologique», nous avait habitués à considérer l'avènement du gouvernement responsable comme une étape vers la finalité du Commonwealth of Nations, le professeur Buckner énonce une proposition ouvertement antithétique: «Responsible government was, after all, a device for retaining 
Imperial control over the colonies, a means of securing the collaboration of the colonial elites in the perpetuation of Imperial rule.» (p. 6)

Une prise de position aussi renversante exigeait une non moins frappante soutenance pour se mériter les honneurs de ce combat historiographique. Mais la défense de l'antithèse s'annonçait d'autant plus difficile que la voie de la démonstration était loin d'être tracée. De toute nécessité il fallait déterminer la démarche à suivre sur un terrain parsemé d'embûches pour soutenir une problématique qui engageait l'auteur à resituer dans une nouvelle perspective historique «la transition au gouvernement responsable». C'était un défi de taille qu'il n'a que partiellement réussi à relever.

Manifestement, le professeur Buckner avait l'ambition de réaliser une oeuvre marquante qui l'a entraîné à se lancer dans une vaste entreprise de reconstitution historique où il s'est évertué à mettre à profit la somme des recherches effectuées depuis les débuts de sa carrière universitaire. Il en est résulté un ouvrage qui impose au lecteur une véritable épreuve de vigilante attention pour suivre le cheminement de son argumentation tout au long de son exposé. Essentiellement, il y manque l'indispensable cohérence de synthèse interprétative qui caractérise les grandes oeuvres destinées à marquer l'historiographie. Et c'est précisément ce défaut fondamental qui «inévitablement» réduira l'effet et la portée des «arguments» du professeur Buckner. Aussi y aurait-il lieu de reprendre le jugement de Ged Martin en le pondérant ainsi: «[Tentatively] this is, in every sense, a giant of a book.»

Avant d'aborder le contenu de l'ouvrage, il importe de considérer la nature antithétique de la problématique de l'auteur pour comprendre sa prise de position combative au regard de l'historiographie. Non seulement se situe-t-il à contre-courant de l'interprétation «whig» dans laquelle a baigné toute l'histoire de la politique coloniale britannique, mais il rejette comme «simplistes» les explications des historiens qui, à l'instar de Robert Levingston Schuyler, ont tenté d'établir un rapport de cause à effet entre la libéralisation de la politique économique selon les principes du «free trade» et l'abandon du «Old Colonial System» ${ }^{1}$. De son point de vue, «the decision to abandon the traditional model of colonial government in the colonies of settlement was neither an inevitable nor an obvious solution to the problem of maintaining Imperial control in British North America» (p. 10). Aussi peut-il soutenir en contrepartie: «From a ministerial perspective the Empire had to be retained and defended simply because it was there.» (p. 6)

1 L'ouvrage de R. L. Schuyler, The Fall of the Old Colonial System: a Study in British Free Trade 1770-1870 (New York, 1945) reprenait en large partie des études parues de 1917 à 1922 dans l'American Historical Review et le Political Science Quarterly. 
La nature antithétique de sa problématique engage l'auteur à mener son combat historiographique sur plusieurs fronts. Ainsi doit-il prendre une position «anti-révisionniste» face à ce qu'il qualifie de «nouvelle orthodoxie» des études réinterprétatives qui ont vu le jour depuis 1950 et dont les plus connues sont celles de Helen Taft Manning ${ }^{2}$ et de John Manning Ward ${ }^{3}$. Il ressort de ces études que l'avènement de la responsabilité ministérielle après l'Union des Canadas ne saurait s'expliquer sans tenir compte des importants changements de conventions survenus entre-temps dans la pratique constitutionnelle du gouvernement métropolitain comme le précise J. M. Ward dans la préface de son ouvrage:

No solutions were adopted until great changes had taken place in the British constitution and in the associated ideas about large colonies of British settlement. British governments granted colonial self-government in various forms, partly in response to pressure from the colonies, but more in accordance with their own notions of what just British polity permitted and required.

Même si cette «nouvelle orthodoxie» comporte le risque de faire de l'évolution de la constitution britannique la clé d'interprétation de l'histoire politique coloniale, elle n'en demeure pas moins fondée historiquement.

Mais loin de reconnaître le fondement historique de cette «nouvelle orthodoxie», le professeur Buckner en proscrit toute valeur explicative. Selon lui, il n'y a pas lieu de mettre en cause les problèmes constitutionnels que soulevait la reconnaissance du principe de la responsabilité ministérielle dans les colonies puisque «the basic principle of Cabinet responsability had been firmly established» depuis le 18e siècle:

Although some of the constitutional conventions of the eighteenth century were to be displaced by others in the nineteenth century (and some of these in turn would be replaced in the twentieth), the essential principle that the ministers of the Crown were responsible to Parliament for the general conduct of the executive government was clearly established in the eighteenth century. (p. 5)

Et à l'appui de cette déconcertante simplification de la réalité, il cite le témoignage de sir Robert Peel qui, au printemps de 1841, soulevait la question de confiance envers le ministère de lord Melbourne en décla-

$2 \quad$ Parmi les plus importantes études de Helen Taft Manning, mentionnons «The Colonial Policy of the Whig Ministers, 1830-1837», Canadian Historical Review, 33,3 et 4 (1952) et «Who Ran the British Empire - 1830-1850?», The Journal of British Studies, 5,1 (1965).

3 J. M. Ward est l'auteur d'un imposant ouvrage intitulé Colonial Self-Government: the British Experience 1759-1856 (Londres et Toronto, Macmillan of Canada, University of Toronto Press, 1976) qui a fait l'objet d'une substantielle revue critique par le professeur Peter Burroughs sous le titre «The Determinants of Colonial Self-Government», The Journal of Imperial and Commonwealth History, 6,3 (1978): 314-329. 
rant que le système de gouvernement parlementaire «which implies that the Ministers of the Crown shall have the confidence of the House of Commons has prevailed in this country since the accession of the House of Hanover». Ayant lui-même souligné ce dernier passage, le professeur Buckner se garde bien de préciser qu'il fallut attendre jusqu'en 1841 pour que le principe de la responsabilité ministérielle passe de la théorie à l'acte et prenne forme concrètement dans une pratique constitutionnelle appelée à devenir normative par la suite. La réalité historique de l'application de ce principe comme mode de fonctionnement constitutionnel importe plus que la fabulation de discours politiques incantatoires. L'année 1841 marqua un changement de conséquence: «A cardinal principle was secured as the result of the debate on Peel's motion of non-confidence in 1841», écrivait il y a plus d'un demi-siècle feu Cecil S. Emden dans un ouvrage devenu classique ${ }^{4}$.

Combien trompeuse a été et demeure la recommandation de lord Durham d'introduire dans un Canada-Uni le principe de gouvernement responsable sans pouvoir (et pour cause!) en déterminer les modalités concrètes d'application. Tout comme sir Robert Peel, il avait assorti son propos d'une argumentation tendant à faire fallacieusement croire que ce principe était acquis depuis le règne de William III dans la pratique constitutionnelle britannique (???): «In England, peut-on lire dans son célèbre Rapport de 1839 , this principle has so long been considered an indisputable and essential part of our constitution, that it has really hardly ever been found necessary to inquire into the means by which its observance is enforced.» Or ce principe supposément «incontestable» constituait alors une question si controversée qu'à la veille de l'Acte d'Union de 1840, le secrétaire colonial, lord John Russell, formulait ainsi ses instructions au gouverneur général Charles Edward Poulett Thomson, futur lord Sydenham:

It appears... that you may encounter much difficulty in subduing the excitement which prevails on the question of what is called «Responsible Government»... It does not appear indeed that any very definite meaning is generally agreed upon by those who call themselves the Advocates of this principle, but its very vagueness is a source of delusion, and if at all encouraged would prove the cause of embarrassment and danger.

S'il faut en croire le professeur Buckner, les autorités britanniques étaient davantage préoccupées par le problème du «self-government» que par la question controversée de la responsabilité ministérielle. La principale difficulté consistait à déterminer quelle part d'autonomie gouvernementale pouvait être concédée aux colonies et, face au dilemme que

4 Cecil S. Emden, The People and the Constitution (Oxford University Press, 1956), 159. Première édition 1933. 
posait «la délimitation des responsabilités impériales et coloniales», le gouvernement métropolitain préféra agir «pragmatiquement» (p. 258). Lorsque fut décidée l'Union des deux Canadas, en 1839, il y avait près d'une décennie que le «Colonial Office had grappled with the question of whether some form of cabinet government could be extended to the British North American colonies» (p. 259). Ainsi, selon l'auteur, doiton comprendre que tout en dénonçant le principe du gouvernement responsable, le secrétaire colonial, lord John Russell, ne pouvait qu'admettre «that it would normally be acted upon in practice» et que, à la suite de ses directives, le gouverneur général, lord Sydenham, avait tôt fait d'en concéder «l'essentiel» (p. 261, 263).

Du point de vue de l'auteur, la question de la responsabilité ministérielle doit être dissociée de celle du gouvernement autonome: «Selfgovernment did not require responsible government, since the Assemblies could gradually acquire executive functions under the old representative system and frustrate Imperial policies», comme le démontre l'exemple des colonies américaines avant leur Déclaration d'indépendance (p. 334). Loin de se représenter l'avènement du gouvernement responsable comme une étape dans le processus de libération coloniale face à la tutelle métropolitaine, il y voit plutôt le moyen «moderne» par excellence de s'assurer la collaboration des élites coloniales et, ainsi, de préserver et de perpétuer le contrôle impérial.

Il nous paraissait nécessaire de bien préciser la nature antithétique de la problématique du professeur Buckner avant d'aborder le contenu de son ouvrage. Indéniablement l'ouvrage recèle un riche contenu analytique qu'il vaudrait de passer en revue pour rendre pleine justice à son auteur. Mais compte tenu de l'orientation déjà donnée à notre note critique, nous nous limiterons ici à retracer le long et laborieux cheminement auquel l'a entraîné sa vaste entreprise de reconstitution historique. Soyons clair à ce sujet: la voie démonstrative qu'il a choisie comportait trop d'entraves à l'élaboration d'une oeuvre de synthèse interprétative pour ne pas y avoir achoppé.

Le fait même qu'il faille se reporter à la conclusion de l'ouvrage pour trouver une esquisse de synthèse interprétative est révélateur de la démarche suivie par l'auteur. «Between 1815 and 1850, y lit-on, a revolutionary change took place in the structure of colonial government in British North America.» (p. 333) Voilà une justification pour le moins surprenante de la périodisation de sa reconstitution historique sachant que tout son exposé tend à démontrer que rien de tel ne s'est produit. Loin d'avoir donné lieu à un «changement révolutionnaire», la perpétuation, après 1783, du «vieux système» de gouvernement colonial hérité du «First British Empire» (celui d'avant la Révolution américaine) prolongea indûment l'«inévitable» transition au système moderne de gouvernement responsable qui caractérisa le «Second British Empire». 
Malgré ses faiblesses, ce «vieux système» de gouvernement comportait suffisamment de souplesse pour permettre aux colonies d'obtenir «an ever greater measure of self-government». Ainsi s'explique, selon l'auteur, qu'il ait pu fonctionner tant bien que mal «so long as the colonial elites were convinced that the advantages of the Imperial connection outweighed the disadvantages, and the Imperial Government was flexible and conciliatory» (p. 334).

Qu'il ait fallu attendre jusqu'en l'année décisive de 1839 pour que les autorités métropolitaines comprennent enfin que le développement des colonies de l'Amérique du Nord britannique nécessitait la modernisation du système de gouvernement colonial situe d'emblée dans la longue durée l'histoire de la «transition» reconstituée par le professeur Buckner. De fait son histoire remonte à l'avènement du régime constitutionnel de 1791 auquel il réserve un chapitre entier intitulé «The Old Representative System in Theory and in Practice» pour en étudier le fonctionnement tant au Bas qu'au Haut-Canada que dans les provinces de Nouvelle-Écosse et du Nouveau-Brunswick. Il en ressort que si, en théorie, ce «vieux système représentatif» devait assurer aux autorités impériales le contrôle de l'initiative au sein des gouvernements coloniaux, en pratique, sous l'effet d'un «inévitable» processus évolutif, cette initiative passa graduellement aux mains des élus du peuple qui en vinrent à assumer les responsabilités dévolues à l'exécutif.

L'auteur consacre les quatre chapitres suivants à couvrir l'histoire des principaux événements qui, de 1815 à 1837 , ont marqué la mise à l'épreuve du régime constitutionnel de 1791, notamment au Bas-Canada. Composant une volumineuse partie de son ouvrage (p. 92-249), ces quatre chapitres nous renseignent beaucoup sur l'organisation, le fonctionnement et le personnel politique du Colonial Office. La connaissance approfondie du professeur Buckner nous permet de mieux comprendre les différentes tentatives de conciliation qui, du côté métropolitain, furent faites en vue de gagner la collaboration des élites coloniales. Son analyse exhaustive l'entraîne à réserver un chapitre complet à «l'évolution du programme de conciliation», de 1827 à 1833 . Il s'en dégage que, malgré tous leurs efforts, «the officials in London had not resolved the fundamental problem: how to evolve a working relationship between the Canadian Assemblies and the executive authority» (p. 166). Et c'est ainsi que ceux qui prirent la relève du secrétaire colonial, lord Goderich, et du sous-secrétaire, lord Howick, futur earl Grey, héritèrent du «même noeud gordien».

De 1833 jusqu'à l'avènement des rébellions de 1837 au Bas et au Haut-Canada, les autorités londoniennes jonglèrent avec ce noeud gordien sans parvenir à le trancher. Dans les deux chapitres consacrés à cette période troublée, l'auteur poursuit sa démarche analytique pour exposer au grand jour la valse-hésitation qui caractérisa la politique du 
Colonial Office jusqu'en 1837. La radicalisation de la lutte menée par la direction du parti patriote au Bas-Canada produisit «a fundamental change in the structure of politics in the colony», entre 1833 et 1835 (p. 190). Le vote sur les Quatre-vingt-douze Résolutions contribua à raffermir les positions du parti patriote et à les démarquer des autres partis politiques: «What united the patriotes was a commitment to mass participation in politics and to colonial self-determination.» (p. 190) Dès lors la politique de conciliation du gouvernement métropolitain était vouée à l'échec: «The fundamental flaw in the policy of the British Government was the assumption that an accommodation with the elites in French Canada was possible on terms that would leave the British Government with sufficient authority to resist the more extreme demands of the patriotes.» (p. 191) Et l'auteur enchaîne en comparant la situation au Bas-Canada avec celle des autres colonies de l'Amérique du Nord britannique:

Elsewhere in British North America this assumption was valid, for the colonial elites were prepared to collaborate in maintaining Imperial authority. Their willingness was not based solely upon cultural affiliation, but also upon the advantages that the British connection bestowed upon the colonies. Britain was a dynamic and expanding society and the colonial elites were easily persuaded to surrender some of their autonomy in return for access to British markets, the encouragement given to the influx of British capital, immigrants and technology, and the military and diplomatic protection of the Imperial government.» (p. 191)

Mais ces «avantages» ne pouvaient représenter le même attrait pour la majorité de la population canadienne-française du Bas-Canada qui vivait «dans des communautés rurales où l'agriculture de subsistance était la norme» (p. 191). Aussi les dirigeants du parti patriote n'eurent-ils d'autre choix que de se gagner un large support populaire parmi ces «traditionalist elements in a preponderantly pre-industrial society» (p. 192). Le lecteur avisé saura faire la part des choses dans ces considérations d'inspiration creightonienne et ouelletienne.

La mobilisation des forces rurales «traditionalistes» d'une société coloniale préindustrielle aura eu au moins le bon effet de favoriser ce que le professeur Buckner qualifie de «changement révolutionnaire» soit, en fait, l'accélération du processus de transition au système moderne de gouvernement responsable. Il fut donné à lord Durham de reconnaître «plus clairement que tout autre» cette nécessaire modernisation du système de gouvernement colonial:

Durham's greatest achievement was his recognition that the political institutions of the larger North American colonies were inadequate for their needs and had to be restructured upon an entirely different principle than that upon which the old representative system had been based. (p. 335) 
Et conformément à ses recommandations, les changements qu'introduisirent le secrétaire colonial, lord John Russell, et le gouverneur général, lord Sydenham, dans la province du Canada-Uni - changements qui furent graduellement appliqués dans les autres colonies de l'Amérique du Nord britannique - «established the framework of a new relationship between the government and the governed». En ce sens, conclut l'auteur, «the Durham Report did lead to the dawn of a new conception about the role of the executive in the colonies and altered irrevocably the structure of the old colonial system» (p. 335).

Cette reconnaissance du rôle joué par lord Durham sera sans doute perçue comme «anti-révisionniste» par les tenants de la «nouvelle orthodoxie» qui, avec Ged Martin en tête ${ }^{5}$, ont entrepris de démystifier la supposée influence déterminante du célèbre Rapport de 1839 sur les décisions des autorités britanniques. Une entreprise de démystification que le professeur Buckner juge avoir été poussée «trop loin» en réaction à l'historiographie glorifiante inspirée de la plus pure tradition «whig» qui avait fait du fameux document la «Magna Carta» du «Second British Empire». L'interprétation historique parviendra-t-elle un jour à échapper aux extrêmes oscillations du balancier des opinions humaines???

Par l'intitulé du dernier chapitre «Yielding to the Inevitable, 18461850», l'auteur en arrive au point d'aboutissement de son ouvrage: l'avènement du gouvernement responsable. Son interprétation est si divergente de celle du grand courant historiographique traditionnel qu'il vaut d'en signaler le contraste en citant l'un des plus illustres représentants, sir Reginald Coupland ${ }^{6}$ :

The case for Responsible Government presented in the Durham Report did not convince Russell, still less his Tory successors. Only the second part of Durham's advice was implemented [l'Union des deux Canadas]... The more vital... concession of Responsible Government had to wait till Durham's brother-in-law, lord Grey, was at the Colonial Office, and the final confirmation of it in practice till Durham's son-in-law, lord Elgin, was Governor of United Canada.

Ainsi l'heureuse alliance du beau-frère, le troisième earl Grey, nommé en juillet 1846 au poste de secrétaire colonial, et du gendre de lord Durham, le huitième earl of Elgin arrivé au Canada en janvier 1847 comme gouverneur général, rendit possible l'avènement du gouverne-

\footnotetext{
5 Voir son percutant et provocant livre The Durham Report and British Policy. A Critical Essay (Cambridge, England, Cambridge University Press, 1972).

6 Dans une série de conférences prononcées à l'Université de Londres, pendant l'hiver 1928-29, et qui furent publiées sous le titre The American Revolution and the British Empire (Londres, 1930). Le passage cité est tiré de la huitième et dernière conférence où il est question de la constitution de 1791 et de ses suites historiques.
} 
ment responsable. Entre-temps, l'autoritaire gouverneur sir Charles Metcalfe avait opposé une fin de non-recevoir à la poursuite de l'initiative prise par son prédécesseur, sir Charles Bagot, de tenter l'expérience de la responsabilité ministérielle avec les chefs réformistes du Bas et du Haut-Canada.

Voyons ce que pense de tout cela le professeur Buckner:

Grey did not introduce responsible government into Canada. The commitment that the executive would be responsible to the legislature had been made by Russell and Sydenham, confirmed by Bagot's decision to admit the Baldwin-Lafontaine reformers into the Executive Council, and reaffirmed by Stanley and Metcalfe. (p. 338)

La clé de cette interprétation contrastante nous est fournie par la problématique de l'auteur qui est de nature antithétique par rapport à l'historiographie ainsi qu'il a pris soin de nous prévenir dès le point de départ: «Responsible government was, after all, a device for retaining Imperial control over the colonies, a means of securing the collaboration of the colonial elites in the perpetuation of Imperial rule.» (p. 6)

Voilà ce qui explique pourquoi Ged Martin termine son élogieux compte rendu de l'ouvrage du professeur Buckner par ce commentaire tout à fait significatif: «Whether his arguments are accepted in full or not, this book will certainly be the starting point for future debate on the coming of self-government.» Nous avons souligné cette dernière expression qui dénote un lapsus fort révélateur sous la plume d'un représentant de la «nouvelle orthodoxie». Si nos lecteurs saisissent que l'auteur de The Transition to Responsible Government se serait pour sa part gardé d'employer le terme de «self-government», cette note critique n'aura pas été composée inutilement. 